\title{
Dietary fads and gut mysteries versus nutrition with a grain of common sense
}

\author{
Barry Mishkin MD, Seymour Mishkin MD FRCPC FACP
}

\begin{abstract}
B Mishkin, S Mishkin. Dietary fads and gut mysteries versus nutrition with a grain of common sense. Can J Gastroenterol 1997;11(4):371-375. Although nutritional self-help literature is directed at the general public, which usually allows the authors to evade critical review by the medical and scientific community, both doctors and lay people need to read with discernment and educated scepticism when major health claims are made. Many published claims are based on misconceptions and questionable logic, and it is important to be aware of the inconsistencies and wrong conclusions commonly found in dietary fads. Patients' questions and dietary practices over the past few years have helped the present authors become familiar with certain food fads and nutrition 'self-help' books, and develop responses to popular gut topics such as food allergies, food combinations and commercial food supplements. The authors also discuss whether fads can deliver on their promises and what to tell patients.
\end{abstract}

Key Words: Dietary fads, Health claims, Nutrition, Popular books

\section{Modes alimentaires et charlatanneries versus bon sens et nutrition}

RÉSUMÉ : Bien que la littérature grand public sur la nutrition permette en général aux auteurs d'éluder l'oeil scrutateur de la communauté médicale et scientifique, les médecins et monsieur tout-le-monde doivent considérer avec circonspection et un sens critique de bon aloi toute prétention d'importance en matière de santé. Après avoir pris des notes sur les questions et les pratiques alimentaires de leurs patients au cours des quelques dernières années, les auteurs se sont familiarisés avec certaines modes alimentaires et certains livres grand public sur la nutrition. Plusieurs des théories énoncées se fondent sur des idées fausses et une logique douteuse et il est important d'être conscient des discordances et des conclusions erronées que l'on trouve souvent dans ces bouquins. Après avoir parlé avec leurs patients, les auteurs du présent article ont mis au point des réponses pour répliquer aux affirmation à l'emporte-pièce qu'ils peuvent vous servir sur les allergies alimentaires, les combinaisons alimentaires et les suppléments alimentaires vendus dans le commerce. Les auteurs précisent également si les promesses sont fallacieuses et proposent des réponses à l'intention des patients.
A s a result of our patients' questions and dietary practices over the past few years we have become familiar with certain food fads and nutrition 'self-help' books that often promise to reveal the secrets of digestion and good health (Table 1). Discussions with our patients have helped us develop responses to claims of these popular books. Many published claims are based on misconceptions and questionable logic, and it is important to be aware of the inconsistencies and wrong conclusions commonly found in dietary fads.

Nutritional self-help literature is directed at the general public, which usually allows the authors to evade critical review by the medical and scientific community. The writers appear impressive and credible when they refer to the literature and quote from published studies. However, both doc-

\section{AUTHOR PROFILES}

Barry Mishkin is a senior resident in Internal Medicine at the Montefiore Medical Center, Bronx, New York. He qualified from the Albert Einstein College of Medicine, Bronx, New York.

Seymour Mishkin is an Associate Professor of Gastroenterology in the Faculty of Medicine at McGill University, Montreal, Quebec. He qualified from McGill University, The Johns Hopkins Hospital, Baltimore, Maryland and the Albert Einstein College of Medicine. He is the Director of the Inflammatory Bowel Disease Clinic (IBD) at the Royal Victoria Hospital, Montreal, Quebec and Co-Chair of the IBD Nutrition Review Forum. He is an Associate Editor (Nutrition) of The Canadian Journal of Gastroenterology.

Montefiore Medical Center, Bronx, New York; and Royal Victoria Hospital, Montreal, Quebec

Correspondence and reprints: Dr S Mishkin, Royal Victoria Hospital, Room A3.09, 687 Pine Avenue West, Montreal, Quebec H3A 1A1.

Telephone 514-843-1578, fax 514-931-2233, e-mail dmishk@po-box.mcgill.ca

The opinions expressed are those of the authors and do not necessarily reflect those of the other members of the IBD Nutrition Review Forum

Received for publication January 23, 1997. Accepted January 30, 1997 
TABLE 1

\section{Popular dietary fad books}

Breaking the Vicious Cycle: Intestinal Health Through Diet, by Elaine Gottschall. Kirkton: The Kirkton Press, 1994

Dine Out and Lose Weight, by Michel Montignac. Los Angeles: Montignac USA, Inc, 1987

Eating Right For a Bad Gut - The Complete Nutritional Guide to Ileitis, Colitis, Crohn's Disease and Inflammatory Disease, by James Scala. New York: Penguin Books, 1990

Encyclopedia of Natural Medicine, by Michael Murray and Joseph Pizzorno. Raklin: Prima Publishing, 1991

Fit for Life II. Living Health, by Harvey and Marilyn Diamond. New York: Time Warner Co, 1988

Food and the Gut Reaction - Intestinal Health Through Diet for Crohn's Disease, Ulcerative Colitis, Diverticulitis, Celiac Disease, Cystic Fybrosis, Chronic Diarrhea, by Elaine Gottschall. Kirkton: The Kirkton Press, 1987

Internal Cleansing - A Practical Guide to Colon Health, by Linda Berry. Capitola: Botanica Press, 1985

Intestinal Toxicity and Inner Cleansing, by Jeffrey Bland. New Canaan: Keats Publishing Inc, 1987

The Joy of Health - A Doctor's Guide to Nutrition and Alternative Medicine, by Zoltan P Rona. Willowdale: Hounslow Press, 1991

Prescription for Longevity - Eating Right for a Long Life, by James Scala. New York: Penguin Books, 1992

Prescription for Nutritional Healing, by James F Balch and Phylis A Balch. New York: Avery Publishing Group Inc, 1990

Seven Weeks to a Settled Stomach - Free Yourself from Digestive Pain Forever, by Ronald L Hoffman. New York: Simon \& Shuster Inc, 1990

The Yeast Connection - A Medical Breakthrough, by William G Crook. New York: Random House, 1983

tors and laymen need to read with discernment and educated scepticism when major health claims are made.

\section{THE ALLERGY SCARE}

Self-help authors often talk about food allergies but quote studies from the first quarter of the century. In that era the criteria for allergic food reactions were seldom objective and certainly did not meet today's accepted definitions. Also, many food reactions are actually an 'intolerance' of certain foods or 'nonimmunological adverse reactions'. Regardless, 'food faddists' often prohibit the intake of eggs, milk and gluten, offenders commonly identified in early studies but seldom confirmed by up-to-date antibody testing and double-blind placebo controlled challenges. In addition to being costly, time-consuming and socially isolating, such restrictive diets can result in unnecessary weight loss and even malnutrition.

\section{HOW UNHEALTHY IS TABLE SUGAR?}

Self-help food gurus often advise readers to stay away from sugar. They may conjure up images of bacteria and yeast flourishing in our innards thanks to our excess intake of 'sa- tanic sucrose' and other sugars. Advice to avoid various sugars is often excessive and inconsistent, and is almost always unfounded. Some authors permit 'wholesome' sweeteners such as honey, despite its high concentration of fructose. However, using a $25 \mathrm{~g}$ challenge, more than $50 \%$ of the population absorbs fructose poorly.

Despite its cavity-causing potential, sucrose is actually a benign sweetener that is inexpensive and easily digested and absorbed, except in Inuits in Greenland in whom sucrose malabsorption is $5 \%$. This group also manifests an unusually high (approximately 15\%) prevalence of trehalose (a disaccharide found in mushrooms and algae) malabsorption. The component sugars of sucrose, fructose and glucose, facilitate one another's absorption when consumed as the sucrose disaccharide. Sucrose is much more inexpensive than other forms of sugar and is a low-calorie substance $(15 \mathrm{Kcal} / 5 \mathrm{~mL})$ when taken in moderation.

Physicians must recognize that sugar malabsorption is a common and usually benign occurrence. The well-known symptoms associated with sugar malabsorption may include bloating, cramps and diarrhea. Patients should be objectively evaluated after tests with various sugars. We commonly screen with challenges of lactose $(25 \mathrm{~g})$, fructose $(25 \mathrm{~g})$ and sorbitol $(5 \mathrm{~g})$ before advising any dietary restrictions. Following recommendations made in certain food fad books will result in unnecessary avoidance of the sweeter things in life.

\section{CONFUSION OVER FOOD COMBINATIONS}

Certain dietary fad books claim that incorrect food combinations can cause discomfort and even disease. For example, in Fit for Life II (1) the authors state that "proteins and starches can not be digested efficiently in the stomach at the same time...undigested protein putrefies and undigested starch ferments resulting in acid indigestion, gas, flatulence, heartburn, upset stomach". They advise readers that "the single most beneficial habit you can possibly cultivate is the habit of consuming exclusively fresh fruit and fresh fruit juice from the time you awaken in the morning until 12:00 noon". The authors go beyond this recommendation to declare that "eating a traditional breakfast is one of the most unhealthful dietary habits in existence" and that "the archaic notion that we need to eat from each of the four basic food groups at every meal is probably responsible for more digestive difficulties than any other dietary habit we have". These dictums certainly fly in the face of conventional nutrition and physiological knowledge. Based on our knowledge, questioning of colleagues and perusal of the literature on absorptive physiology, we are unable to support or refute these claims. To date, the best answer comes from chemist Joe Schwarcz, who is also the Co-Chair of the Inflammatory Bowel Disease Nutrition Review Forum:

Energy consumed by metabolism can be measured in a calorimeter or by amount of oxygen consumed. Ingestion of food increases oxygen consumption and metabolic rate by $10-20 \%$ after eating. This effect of food is known as 
the "specific dynamic action [SDA]". Protein gives the greatest effect; fats and carbohydrates less, but the cause is not the energy expended in the digestion and absorption of food. This accounts for only a small fraction of increased metabolic rate. This can be shown by intravenous administration of amino acids which produces the same SDA effect as orally. The increased metabolic rate is due to liver activity through processing of exogenous nutrients. The SDA is about one tenth the BMR [basal metabolic rate] and the effect of digestion is a small fraction of this. Therefore the implication that improper digestion robs the body of energy is nonsense. Furthermore, the notion that some foods are predigested because of enzymes is ridiculous. Foods do not contain digestive enzymes.

Regarding the warnings against combining food groups, Dr Schwarcz reminds us "the burden of proof is on the claimant - extraordinary claims require extraordinary proof". In this regard, an interesting comment was made by Dr Greg Dubord, an Area Network Co-ordinator (Canada) of the National Council Against Health Fraud. He indicated that if the diet fad proponents were truly interested in testing their theories they could channel some of their profits to recruit teams of skilled researchers whose funding has been cut back.

\section{THE 'DINE-IN-STYLE' DIET}

An example of a program for weight reduction and healthy eating is presented by Michel Montignac in Dine Out and Lose Weight (2). This enticing book skilfully delivers a message reminiscent of that in Fit for Life II. The author capitalizes on the 'French paradox' - that the French have the lowest incidence of heart disease in the western world despite a daily diet that includes butter, charcuterie, oil, foie gras, fresh cream, cheese and wine. Possible explanations include consumption of most daily calories before 14:00; calcium consumption from cheese; red wine connection via flavonoids with antioxidant properties such as resveratrol; higher intake of minimally cooked fruits and vegetables containing antioxidants such as vitamin $\mathrm{C}$ and $\mathrm{E}$, as well as beta carotene; generally a carefree lifestyle; inaccurate statistics due to use of the term "sudden death" instead of "heart attack" on death certificates. (In this world, one seldom gets something for nothing. Even if the incidence of heart disease is really lower in France, excesses should be avoided; chronic diseases are associated with high alcohol intake and gluttony.)

Although high calorie foods are permitted according to Dine Out and Lose Weight, the net result of the other restrictive aspects of the diet leads to a reduction in total caloric intake. Other 'faddist' advice includes the avoidance of bad carbohydrates and certain food combinations (eg, protein and carbohydrates). According to this program, 'bad' carbohydrates include sugars, syrups, honey, jams, jellies, cakes, cookies, pasta, pizza, potatoes, corn, semolina, couscous, refined cereals, alcohol and most chocolate. 'Good' carbohydrates include whole cereals (wheat, oats, barley, millet),
TABLE 2

Characteristics of 'dietary fads' compared with those of conventional medicine

\begin{tabular}{lcc}
\hline Characteristic & Medical practitioner & Food faddist \\
\hline $\begin{array}{l}\text { User-friendly } \\
\text { Placebo response }\end{array}$ & Variable & Always \\
Medications & Encourage $^{*}$ & Maximum \\
$\begin{array}{l}\text { Basis for hypothesis } \\
\text { Justification of } \\
\text { efficacy }\end{array}$ & Medical data $^{\dagger}$ & $\begin{array}{c}\text { Discourage } \\
\text { 'Grain of truth'‡ }\end{array}$ \\
$\begin{array}{l}\text { Controls } \\
\begin{array}{l}\text { Scientific evidence } \\
\text { Protection for clients }\end{array}\end{array}$ & $\begin{array}{c}\text { Testimonials } \\
\text { Professional and }\end{array}$ & None \\
& Legal recourse & $\begin{array}{c}\text { None/'Skilful } \\
\text { disclaimers' }\end{array}$ \\
\hline
\end{tabular}

* Medication recommendations are based on placebo controlled studies (phase III) once efficacy and safety, as well as target population, have been defined (phase I and II studies); nutritional and dietary recommendations are based on physiological and biochemical studies in vivo (humans and laboratory animals) as well as in vitro; ${ }^{\dagger}$ Often dry, incomplete, contradictory; ${ }^{\sharp}$ Imaginative hypo-theses often based on poor logic and leaps of faith. Bibliographies may be impressive

\section{TABLE 3}

Books claiming to explain the misconceptions in dietary fads

\begin{tabular}{l}
\hline The Vitamin Pushers: The "Health Food" Industry is Selling \\
America a Bill of Goods, by Stephen Barrett and Victor Herbert. \\
New York: Prometheus Books, 1993 \\
Consumer Health Library (more than 10 titles), Stephen Barrett \\
(series editor); Manfred Kroger (technical editor). New York: \\
Prometheus Books
\end{tabular}

whole wheat flour products, beans, fruit and chocolate with more than $60 \%$ cocoa. 'Excellent' carbohydrates include legumes, vegetables and beans. The nutritionally sound, albeit less glamorous, weight reduction programs advised by welltrained conventional dieticians may have trouble competing with this food philosophy. Montignac's discussion of fibre and his measures to control cholesterol and heart disease are laudable, but the chapters devoted to hypoglycemia, digestion and wine cures include unproven claims and cannot be endorsed. A colleague who succeeded in losing $11.3 \mathrm{~kg}$ by using the Montignac methods credits the achievement to a change in eating habits. He readily admits that he was unable to swallow the theory behind this diet fad.

\section{MEDIA SAVVY: HOW AUTHORS USE THE SOUND BITE}

Advocates of food fads often capitalize on the public's fear of disease and the medical profession. They have also mastered the use of testimonials to prove that adherence to their diets works wonders that are rarely achieved by conventional medicine and prescription drugs. These authors can entice receptive audiences with a skilful blend of catch words and phrases, eg, we contain "pollution and toxins" in our bodies because we consume "adulterated", "overcooked", "chemically processed", "devitalized" "irradiated", "pasteurized" and 
TABLE 4

Publications recommended to patients for nutritional information

Health after 50 - Taking Control of Your Own Health and Medical Care, from the Johns Hopkins Hospital. Send subscription inquires to Subscription Department, Health After 50, PO Box 420179, Palm Coast, FL 32142, USA, or telephone 904-446-4675

Mayo Clinic Health Letter - Reliable Information for a Healthier Life. Send subscription inquires to Subscription Services, PO Box 53889, Boulder, CO, USA, or telephone 803-223-3889

Wellness Letter - The Newsletter of Nutrition, Fitness and Stress Management, out of the University of California at Berkeley. Send subscription inquiries to PO Box 420148, Palm Coast, FL 32142, USA, or telephone 904-445-6414

\section{TABLE 5}

\section{Some nutrition books put out by reputable institutions}

Foods that Harm - Foods that Heal, consultant editor Joseph A Schwarcz. Westmount: Reader Digest Association (Canada), 1997

Total Nutrition, co-edited by Victor Herbert and GJ Sbuak-Sharpe from the Mount Sinai School of Medicine. New York: St Martin's Press, 1995

Tuft University Guide to Total Nutrition, by S Gershoff and C Whitney. New York: Harper Collins Publishers, 1994

The Wellness Book, by H Benson and EM Stuart. New York: Fireside, 1992

The Wellness Encyclopedia of Food and Nutrition, by Sheldon Margen and the editors of the University of California at Berkeley Wellness Letter. Write to PO Box 42022, Palm Coast, FL 32142, USA

\section{TABLE 6 \\ Suggested reading regarding diets for inflammatory bowel disease patients \\ Albert V, Gilbert J, Greenberg G, Mishkin S. The 'specific carbohydrate diet': Nutritional quackery or of possible benefit for some IBD patients? Can J Gastroenterol 1996;10:127-30 \\ Mishkin S. Controversies regarding the role of dairy products in inflammatory bowel disease. Can J Gastroenterol 1994;8:205-12 \\ Mishkin S. Dairy sensitivity/lactose malabsorption and elimination diets in inflammatory bowel disease (IBD). Am J Clin Nutr 1997;65:564-7 \\ Mishkin S on behalf of the IBD Nutritional Review Forum. Popular books and alternative medical practices available to our IBD patients - How to react? Can J Gastroenterol 1996;10:342-6}

"fast" foods containing excess cancer- and disease-causing meat. As a result, we have a "build-up of food residues and additives (which are toxic)" and other "nonusable debris". Such slogans and catchy phrases in many popular food fad books could almost be entertaining if they were not so misguided. Here is another sampler: "What the patient takes beyond his ability to digest does harm"; "Health will automatically follow in the wake of a healthy life style"; "Vibrant, glowing health is our natural state of being, and healing is a biological process of the body not an art done to the body"; "Health is free and it is ours to embrace"; "Ever see a rabbit reaching for Rolaids? Ever see a tiger with Tums? A giraffe with Gelusil? Or a panda with Pepto-Bismol?"; and "Having credentials does not make the truth more the truth and not having credentials does not make the truth less the truth".

\section{WHAT ABOUT COMMERCIAL FOOD SUPPLEMENTS?}

An increasing number of television commercials and magazine advertisements show young, active models in the pink of health consuming commercial, partially digested (polymeric) liquid food supplements. This is another undesirable dietary fad that has the producer's financial gain - not the public's health interests - at heart. There is no justification for healthy people who have no apparent digestive problems or malnutrition to consume these supplements in a society that has such ready access to a wide variety of high quality foods. 'Selling nutrition in a can' - the title of a recent "Caveat emptor" (buyer beware) column in the Johns Hopkins Medical Letter Health after 50 - Taking Control of Your Own Health and Medical Care - reaches conclusions very similar to ours (3). In that article they quote the American Pharmaceutical Association statement that "although dietary supplements can be obtained without a prescription, they are complex agents with specific indications, and medical assessment should precede their use". Their list "when supplements make sense" includes chronic illness, mobility problems that make food preparations difficult, swallowing and chewing problems, and weight loss associated with chemotherapy and serious disease. According to the Wall Street Journal, Ensure (Ross Laboratories), the market leader whose advertising budget increased fourfold from 1991 to 1995, increased sales over $100 \%$ during this period to an estimated total of US\$500 million. Pharmaceutical and nutritional supplement producers seem to prefer when sales of their products are consumer-driven rather than taken only on the advice of health care professionals.

\section{CAN FADS DELIVER ON THEIR PROMISES?}

When fad diets encourage regimens high in fruits, vegetables, nuts and seeds, they can certainly be helpful. Once readers untangle themselves from the loose logic and leaps of faith, they may find that much of the information is well founded. To their credit, the dietary faddists are daring to confront the mysteries of the gut. In fact, the concept of food as a determinant of health and disease is a basic component of preventative and lifestyle medicine. In addition, we have only recently begun to recognize the possible roles of bacterial and yeast flora in health and disease. For example, we now know that some products of bacterial metabolism may be involved in carcinogenesis. Also, short chain fatty acids may prevent dysplastic transformation of colonic mucosa. Who can argue with proponents of a healthy active lifestyle coupled with moderation and attention to the food we con- 
sume? Any discussion of vitamins, flavonoids and antioxidants or the benefits of a diet high in soluble and insoluble fibre are certainly useful.

Despite these positive aspects of some popular food programs, readers should be alerted and sceptical when they come across the disclaimers found in many dietary fad books. These sometimes even imply that the patient's physician shares the blame if there is a negative reaction to the program.

\section{WHAT DO WE TELL OUR PATIENTS?}

Too often health care professionals refuse to address patient inquiries regarding the merits of various diets and matters relating to alternative medical practices. Table 2 summarizes some key differences between conventional medicine and food fads. We urge our colleagues to read this and other information in order to be able to discuss the topic intelligently and convincingly with our more and more inquisitive and informed clientele. In recent years a number of books claiming to expose the misguidedness of many dietary fads (Table 3 ) and to provide sound and informative nutritional information (Tables 4,5) have become available. Additional in- formation for inflammatory bowel disease patients is listed in Table 6.

The absence of scientific data to refute the claims of dietary fads should not prevent us from expressing our misgivings about these practices. Such criticism must, however, be done with caution, especially in public and in print. Canadian Tort law holds that when someone makes a statement that is libellous (ie, causes the reputation of an entity to suffer loss) truth is not a defence as it is in the United States.

ACKNOWLEDGEMENTS: We thank Katherine Addleman $\mathrm{PhD}$, Charles Bernstein MD, Dale Dauphinee MD, Joe Schwarcz $\mathrm{PhD}$, Alan Thomson MD and Noel Williams MD for reviewing this manuscript. We acknowledge the help of Christine Kohek in typing and editing.

\section{REFERENCES}

1. Diamond H, Diamond M. Fit for Life II. New York: Time Warner Co, 1988:28-133.

2. Montignac M. Dine Out and Lose Weight. Los Angeles: Montignac USA, Inc, 1987:21-214.

3. 'Selling nutrition in a can'. Johns Hopkins Medical Letter. Health after 50 - Taking Control of Your Own Health and Medical Care, December 1996:3 


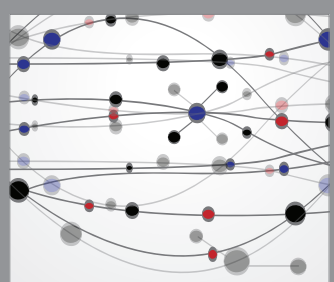

The Scientific World Journal
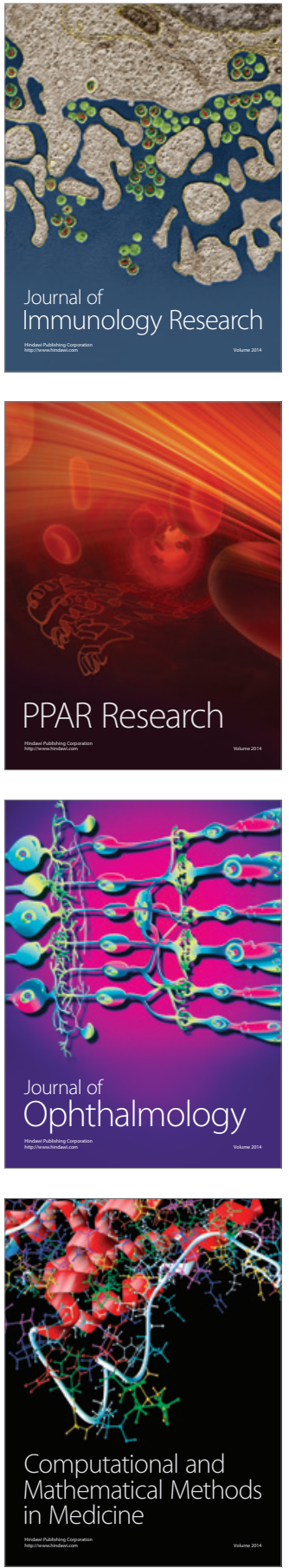

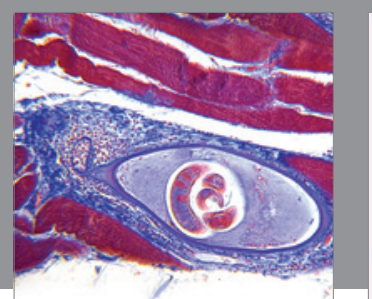

Gastroenterology Research and Practice

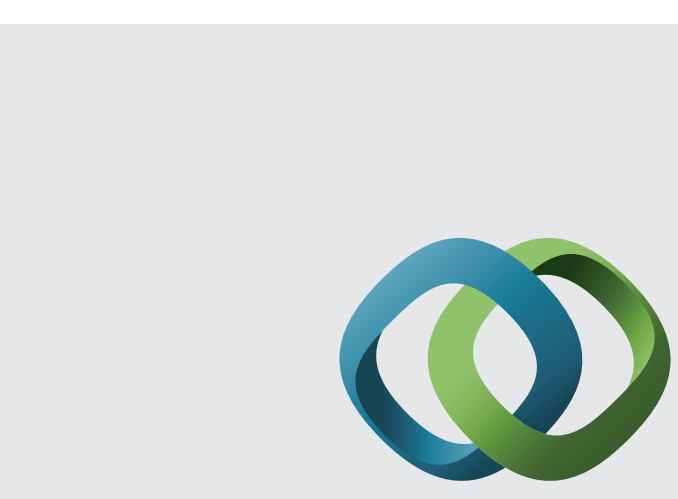

\section{Hindawi}

Submit your manuscripts at

http://www.hindawi.com
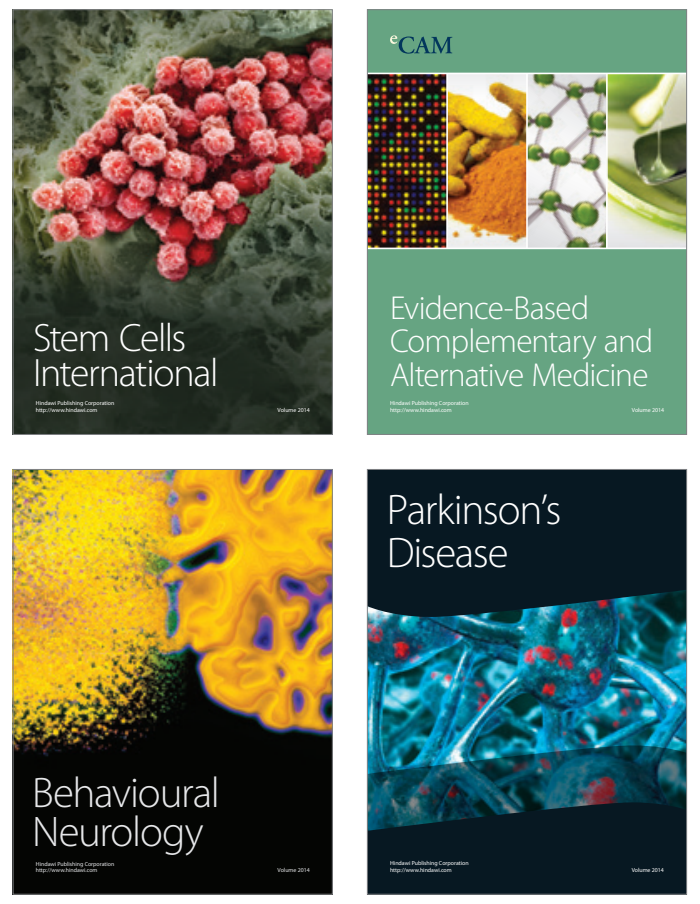
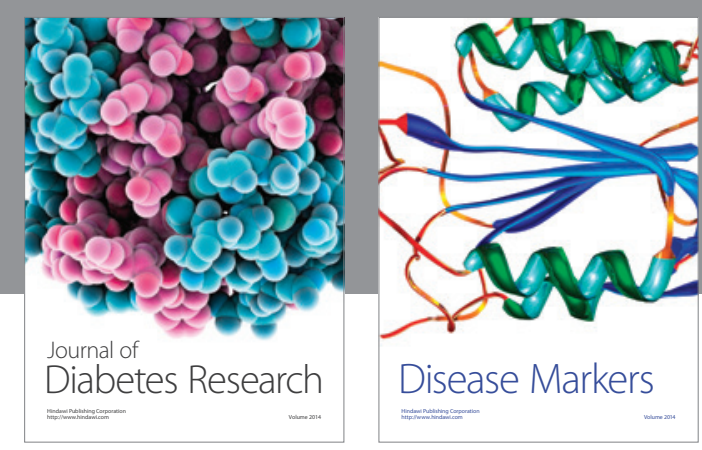

Disease Markers
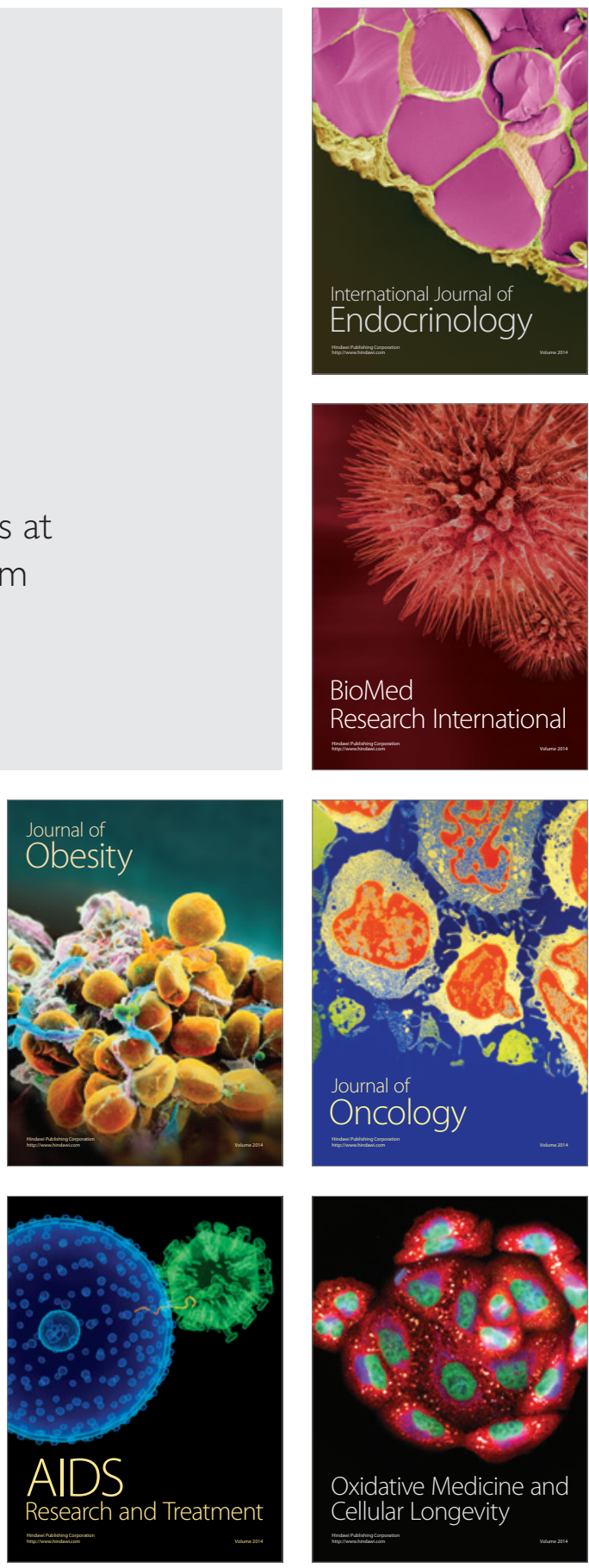